\title{
Faktor-faktor yang mempengaruhi pemanfaatan Program Pengelolaan Penyakit Kronis (Prolanis) pada lansia di Puskesmas Darussalam Medan
}

\author{
Priscilla Grace J Hutagalung*, Rapael Ginting, Hartono, Putranto Manalu \\ Fakultas Kesehatan Masyarakat Universitas Prima Indonesia \\ *Korespondensi: cillagrace69@yahoo.com \\ DOI: doi.org/10.1616/jpms.v2i2.972 \\ (c) 2020 JPMS. All rights reserved
}

\begin{abstract}
Abstrak
Penyakit hipertensi dan diabetes melitus termasuk penyakit terbanyak pada kelompok lanjut usia di Indonesia, yaitu sebesar $57,6 \%$ pada penyakit hipertensi dan 4,8\% pada penyakit diabetes melitus. Dalam upaya pengelolaan penyakit kronis yang cenderung meningkat. BPJS Kesehatan menyelenggarakan program untuk menangani masalah penyakit kronis seperti hipertensi dan diabetes melitus tipe 2 yang bertujuan mendorong peserta penyandang penyakit kronis mencapai kualitas hidup optimal sehingga dapat mencegah timbulnya komplikasi penyakit. Survei awal yang dilakukan peneliti pada bulan Januari tahun 2019 terhadap penderita penyakit kronis di Puskesmas Darussalam menunjukkan bahwa rendahnya kunjungan masyarakat terhadap Program Pengelolaan Pengelolaan Penyakit Kronis (Prolanis) hal ini disebabkan oleh kurangnya dukungan keluarga dimana beberapa pasien datang berkunjung tanpa ada pendamping/keluarga. Tujuan penelitian ini adalah untuk mengetahui faktor-faktor yang mempengaruhi pemanfaatan Prolanis pada lansia di Puskesmas Darussalam Medan. Penelitian ini merupakan jenis penelitian survey analitik dengan rancangan cross sectional. Populasi dalam penelitian ini adalah seluruh penderita hipertensi dan diabetes mellitus baik yang mengikuti kegiatan Prolanis maupun tidak mengikuti kegiatan Prolanis di Puskesmas Darussalam dengan teknik pengambilan sampel secara purposive sampling dan diperoleh besar sampel yaitu sebanyak 92 responden. Data diuji dengan Chi-Square. Hasil penelitian menunjukkan pengaruh yang signifikan antara pengetahuan $(0,003)$ dan dukungan keluarga $(0,001)$ terhadap pemanfaatan Prolanis. Dapat disimpulkan pemanfaatan Prolanis di Puskesmas Darussalam Medan dipengaruhi oleh pengetahuan dan dukungan keluarga responden, sedangkan peran petugas dan kebutuhan akan pelayanan tidak berpengaruh signifikan.
\end{abstract}

Kata kunci: Prolanis, pengetahuan, dukungan keluarga

\begin{abstract}
Hypertension and diabetes mellitus are among the most common diseases among the elderly in Indonesia, namely $57.6 \%$ in hypertension and $4.8 \%$ in diabetes mellitus. In efforts to manage chronic diseases, it tends to increase. BPJS Kesehatan organizes programs to deal with chronic disease problems such as hypertension and type 2 diabetes mellitus which aims to encourage participants with chronic diseases to achieve an optimal quality of life so as to prevent disease complications. The initial survey conducted by researchers in January 2019 of patients with chronic diseases at the Darussalam Puskesmas showed that the low number of community visits to the Chronic Disease Management Program (Prolanis) was due to a lack of family support where some patients came to visit without a companion / family. The purpose of this study was to determine the factors that influence the use of Prolanis in the elderly at Puskesmas Darussalam Medan. This research is a type of analytic survey research with a cross sectional design. The population in this study were all patients with hypertension and diabetes mellitus, both those who participated in the Prolanis activities and those who did not participate in the Prolanis activities at Puskesmas Darussalam with the sampling technique using purposive sampling and obtained a sample size of 92 respondents. Data were tested by Chi-Square. The results showed a significant influence between knowledge (0.003) and family support (0.001) on the use of Prolanis. It can be concluded that the use of Prolanis at Puskesmas Darussalam Medan was influenced by the knowledge and support of the respondent's family, while the role of officers and the need for services did not have a significant effect.
\end{abstract}

Keywords: Prolanis, knowledge, family support 


\section{Pendahuluan}

Program pengelolaan penyakit kronis (PROLANIS) merupakan suatu sistem pelayanan kesehatan dan pendekatan proaktif yang dilaksanakan secara terintegrasi yang melibatkan peserta, fasilitas kesehatan, dan BPJS. Penyakit kronis yang dialami oleh masyarakat akan memberikan dampak dan beban bagi keluarga, bila penanganan dilakukan secara tidak intensif dan berkelanjutan. Manfaat penanganan yang intensif bagi penderita adalah dapat mengenal tanda bahaya dan tindakan segera bila mengalami kegawatdaruratan. Dengan berlakunya Jaminan Kesehatan Nasional sejak Januari 2014, sesuai amanah Undang-Undang No. 40 Tahun 2004 tentang Sistem Jaminan Sosial Nasional dan UndangUndang Nomor 24 Tahun 2011 tentang BPJS, maka Fasilitas Kesehatan Tingkat Pertama (Puskesmas) sebagai garda terdepan dalam memberikan pelayanan kepada masyarakat dapat melaksanakan PROLANIS, melalui kerjasama dengan BPJS untuk melakukan pembinaan bagi penderita penyakit kronis. ${ }^{1}$

Penyakit kronis merupakan jenis penyakit degeneratif yang berkembang atau bertahan dalam jangka waktu yang sangat lama, yakni lebih dari enam bulan. Penyakit kronis menyebabkan ketidakmampuan pada penderitanya, dan untuk menyembuhkannya penderita perlu melakukan perawatan dalam periode waktu yang lama. Penyakit kronis dapat diderita oleh semua kelompok usia, tingkat sosial ekonomi, dan budaya. Penyakit kronis antara lain adalah penyakit hipertensi, diabetes melitus, kanker, dan penyakit paru obstruktif kronik. ${ }^{2}$

Dari laporan WHO mengenai diabetes tahun 2016, secara global diperkirakan 422 juta orang dewasa hidup dengan diabetes di tahun 2014. Diabetes menyebabkan 1,5 juta kematian pada tahun 2012. Glukosa darah yang lebih tinggi dari yang optimal menyebabkan tambahan 2,2 juta kematian, dengan meningkatkan risiko penyakit kardiovaskular dan lainnya. Hipertensi menyebabkan 9,4 juta atau sekitar 7\% kematian di dunia dan diabetes menyebabkan 1,6 juta kematian atau sebesar $4 \%$ kematian di dunia. ${ }^{3}$

Penyakit hipertensi dan diabetes melitus termasuk penyakit terbanyak pada kelompok lanjut usia di Indonesia, yaitu sebesar 57,6\% pada penyakit hipertensi dan $4,8 \%$ pada penyakit diabetes melitus. Adapun prevalensi hipertensi berdasarkan hasil pengukuran pada umur $\geq 18$ tahun sebesar $25,8 \%$ dan prevalensi berdasarkan wawancara sebesar $9,5 \%$ dan prevalensi penyakit diabetes mellitus sebesar 1,5\%. Hasil utama Riset Kesehatan Dasar 2017 menunjukkan prevalensi diabetes melitus berdasarkan kelompok umur 55-64 tahun sebesar 6,3\%. Prevalensi hipertensi menurut karakteristiknya yakni tingkat yang paling tinggi ialah pada kelompok umur 75 tahun sebesar $69,5 \%{ }^{4}$

Dalam upaya pengelolaan penyakit kronis yang cenderung meningkat, BPJS Kesehatan menyelenggarakan program untuk menangani masalah penyakit kronis seperti hipertensi dan diabetes melitus tipe 2. Tujuan Prolanis adalah untuk mendorong peserta penyandang penyakit kronis mencapai kualitas hidup optimal dengan indikator $75 \%$ peserta terdaftar yang berkunjung ke Faskes Tingkat Pertama memiliki hasil "baik" pada pemeriksaan spesifik terhadap penyakit diabetes melitus tipe 2 dan hipertensi sesuai Panduan Klinis terkait sehingga dapat mencegah timbulnya komplikasi penyakit. Kegiatan yang dijalankan dalam Prolanis meliputi aktivitas konsultasi dan edukasi, home visit, aktifitas klub dan pemantauan status kesehatan. ${ }^{1}$

Berdasarkan informasi yang terdapat pada statistik penduduk lansia di Propinsi Sumatera Utara Tahun 2016, hal yang perlu mendapat perhatian yang sangat serius adalah bahwa terdapat 48,10\% lansia dan 45,20\% pra lansia di Sumatera Utara yang tidak memiliki jaminan kesehatan. Padahal seperti yang dijelaskan sebelumnya bahwa kesehatan merupakan hal yang banyak dikeluhkan oleh penduduk lansia maupun pra lansia. Jenis jaminan kesehatan yang banyak dimiliki oleh penduduk lansia dan pra lansia di Sumatera Utara adalah Jamkesmas/PBI, BPJS Kesehatan dan Askes/Asabri/Jamsostek.

Lansia beresiko mengalami penyakit kronis dikarenakan penurunan fungsi tubuh. Faktor lain yang dapat meningkatkan resiko yaitu perilaku keseharian yang kurang baik, seperti 
merokok, alkohol, nutrisi tidak baik, dan lainlain. ${ }^{5}$ Lansia dengan penyakit kronis di Indonesia memiliki jumlah yang cukup tinggi. Sebanyak 28,53\% lansia berusia 60-69 tahun memiliki keluhan kesehatan yang berkaitan dengan penyakit kronis. Persentase ini terus meningkat pada kelompok usia yang lebih tua. ${ }^{6}$

Hasil Riset Kesehatan Dasar (Riskesdas) tahun 2007, diperoleh bahwa penyebab kematian akibat DM pada kelompok usia 45-54 tahun di daerah perkotaan menduduki ranking ke-2 yaitu $14,7 \%$. Dan daerah pedesaan, DM menduduki rangking ke- 6 yaitu $5,8 \%{ }^{7}$ Profil Kesehatan Propinsi Sumatera Utara Tahun 2016 menunjukkan dari sepuluh penyakit terbanyak pada pasien rawat jalan di puskesmas wilayah kerja Kota Medan tahun 20122016, penyakit hipertensi cenderung meningkat. Pada tahun 2012 prevalensi hipertensi sebesar 9,8\% dan meningkat setiap tahunnya hingga tahun 2016 mencapai 16,63\%. ${ }^{8}$

Terkait dengan tujuan dari Prolanis, jumlah peserta Prolanis di Puskesmas Darussalam yaitu 31 peserta tidak sebanding dengan jumlah kunjungan pasien yang menderita hipertensi 723 kunjungan pada tahun 2017 dan 549 kunjungan pasien diabetes melitus pada tahun 2017.

Data dari Profil Puskesmas Darussalam tahun 2017, Puskesmas Darusssalam merupakan bagian dari Pemerintah Kota Medan, yang meliputi dua kelurahan yaitu : Kelurahan Sei Sikambing $D$ dan Kelurahan Sei Putih Barat. Berdasarkan data laporan 10 penyakit terbanyak di Puskesmas Darussalam tahun 2017, penyakit hipertensi berada diurutan kedua dari 10 penyakit terbanyak dan penyakit diabetes mellitus berada diurutan keenam. Jumlah kunjungan hipertensi di Puskesmas Darussalam sebanyak 588 kunjungan pada tahun 2015, sebanyak 675 kunjungan pada tahun 2016 dan 723 kunjungan pada tahun 2017. Jumlah kunjungan diabetes melitus di Puskesmas Darussalam sebanyak 308 pada tahun 2015, sebanyak 378 kunjungan tahun 2016 dan 549 kunjungan pada tahun 2017. Jumlah kunjungan penderita diabetes mellitus dan hipertensi sebanyak 690 kunjungan pada tahun 2015, sebanyak 805 kunjungan pada tahun 2016, dan sebanyak 917 kunjungan pada tahun 2017. Jumlah peserta prolanis pada tahun 2015 penderita diabetes mellitus sebanyak 19 orang, hipertensi sebanyak 20 orang, dan jumlah peserta pada penderita DM dan hipertensi sebanyak 17 orang. Jumlah peserta prolanis pada tahun 2016 penderita diabetes mellitus sebanyak 16 orang, hipertensi sebanyak 16 orang dan jumlah peserta pada penderita DM dan hipertensi sebanyak 14 orang. Jumlah peserta prolanis pada tahun 2017 penderita diabetes mellitus sebanyak 14 orang, hipertensi sebanyak 10 orang dan jumlah peserta pada penderita DM dan hipertensi sebanyak 7 orang. ${ }^{9}$

Berdasarkan hasil data tersebut, diketahui masih rendahnya pemanfaatan Prolanis berdasarkan sasaran yang ditetapkan dalam buku panduan Prolanis dan dari data kunjungan tersebut prevalensi pemanfaatan Prolanis di Puskesmas Darussalam masih mencapai $10 \%$. Dari data kunjungan tersebut juga terlihat bahwa jumlah peserta Prolanis tiap tahunnya semakin menurun.

Penelitian Abdullah (2017) mengenai faktor penyebab terjadinya penurunan jumlah kunjungan peserta program Prolanis di Puskesmas Minasa Upa Kota Makassar menunjukkan bahwa variabel pengetahuan, dukungan keluarga, serta peran petugas memiliki hubungan yang signifikan terhadap pemanfaatan program pengelolaan penyakit kronis. Peserta Prolanis yang tidak rutin berkunjung dan melakukan kegiatan prolanis, maka akan memicuh terjadinya komplikasi bagi penderita resiko tinggi, sehingga tidak dapat memelihara dan meningkatkan derajat kesehatan yang lebih baik. ${ }^{10}$

Penelitian Rahmi (2015) mengenai faktorfaktor yang berhubungan dengan pemanfaatan program pengelolaan penyakit kronis (Prolanis) di BPJS Kesehatan Kantor Cabang Jakarta Timur menunjukkan bahwa terdapat hubungan yang signifikan antara pendidikan, dukungan keluarga, dukungan dokter dengan pemanfaatan Prolanis. Sedangkan karateristik, variabel aksesibilitas menuju Fasilitas Kesehatan Tingkat Pertama, keseriusan, kerentanan penyakit dan hambatan Prolanis tidak ditemukan hubungan yang signifikan dengan pemanfaatan Prolanis. ${ }^{11}$

Dari hasil survei awal yang dilakukan peneliti pada bulan Januari tahun 2019 terhadap penderita penyakit kronis di Puskesmas Darussalam menunjukkan bahwa rendahnya kunjungan masyarakat terhadap program 
pengelolaan pengelolaan penyakit kronis (Prolanis). Hal ini disebabkan oleh kurangnya dukungan keluarga di mana beberapa pasien datang berkunjung tanpa ada pendamping/keluarga. Terdapat beberapa pasien penyakit kronis yang belum tahu adanya Program dari BPJS yaitu Prolanis yang khusus menangani penyakit hipertensi dan diabetes mellitus karena masyarakat belum pernah diberikan sosialisasi khusus Prolanis. Hal ini menunjukkan bahwa penderita masih merasa belum membutuhkan pelayanan program pengelolaan penyakit kronis di Puskesmas Darussalam. Minimnya sosialisasi Prolanis terhadap lansia sehingga banyak lansia yang tidak mengetahui adanya program Prolanis di Puskesmas. Sebagian besar peserta Prolanis juga datang bersama dengan teman sesama peserta daripada diantar ataupun ditemani oleh keluarga. Penelitian ini bertujuan untuk mengetahui faktor-faktor yang memengaruhi pemanfaatan Prolanis di Puskesmas Darussalam .

\section{Metode Penelitian}

Penelitian ini merupakan penelitian survei analitik dengan rancangan penelitian crosssectional untuk mengetahui hubungan variabel yang satu dengan variabel yang lain, hanya satu kali pada satu saat. Penelitian dilaksanakan di Puskesmas Darussalam Medan Petisah pada bulan Juli 2019. Puskesmas ini terletak di Jalan Darussalam no. 40 Kelurahan Sei Sikambing D Kecamatan Medan Petisah. Populasi dalam penelitian ini adalah seluruh jumlah kunjungan penderita hipertensi dan diabetes mellitus baik yang mengikuti kegiatan Prolanis maupun tidak mengikuti kegiatan Prolanis di Puskesmas Darussalam. Berdasarkan data Puskesmas Darussalam tahun 2017, diketahui jumlah penderita hipertensi dan diabetes mellitus sebesar 1.272 jiwa. Pengambilan sampel dengan teknik purposive sampling. Adapun kriteria yang diambil peneliti yaitu lansia yang menjadi peserta Prolanis dan berumur 60 tahun ke atas. Pengumpulan data dalam penelitian ini dilakukan dengan wawancara responden dengan menggunakan alat bantu kuesioner. Analisis data dalam penelitian ini menggunakan uji Chi-Square.

\section{Hasil dan Pembahasan}

Pada tabel 1 dapat dilihat bahwa jumlah responden berdasarkan karakteristik jenis kelamin, laki-laki berjumlah 51 (55,4\%) dan perempuan berjumlah 41 (44,6\%). Mayoritas responden berumur 71-80 tahun berjumlah 32 orang $(34,8 \%)$ dan responden berumur $81-90$ tahun berjumlah 9 orang $(9,8 \%)$. Responden berpendidikan SMP berjumlah 39 orang $(42,4 \%)$, responden berpendidikan SD sebanyak 9 orang $(9,8 \%)$. Mayoritas responden tidak bekerja berjumlah 35 orang $(38,0 \%)$ dan minoritas responden bekerja sebagai pedagang dan wiraswasta berjumlah 16 orang $(17,4 \%)$.

Pada variabel pengetahuan, mayoritas responden dengan kategori tidak baik sebanyak 55 orang $(59,8 \%)$ dan minoritas responden adalah dengan kategori baik sebanyak 37 orang (40,2\%). Sedangkan pada peran petugas, responden adalah dengan kategori tidak baik sebanyak 59 orang $(64,1 \%)$ dan responden adalah dengan kategori baik sebanyak 33 orang (35,9\%). Berdasarkan dukungan keluarga, responden adalah dengan kategori tidak baik sebanyak 50 orang $(54,3 \%)$ dan responden adalah dengan kategori baik sebanyak 42 orang $(45,7 \%)$.

Pada aspek kebutuhan akan pelayanan, responden dengan kategori tidak baik sebanyak 49 orang $(53,3 \%)$ dan responden dengan kategori baik sebanyak 43 orang $(46,7 \%)$. Berdasarkan pemanfaatan Prolanis, responden yang tidak memanfaatkan Prolanis sebanyak 52 orang $(56,5 \%)$ dan responden yang memanfaatkan Prolanis sebanyak 40 orang $(43,5 \%)$. 
Tabel 1. Karakteristik responden

\begin{tabular}{|c|c|c|}
\hline & Jumlah (n) & Persentase (\%) \\
\hline \multicolumn{3}{|l|}{ Jenis Kelamin } \\
\hline Laki-Laki & 51 & 55,4 \\
\hline Perempuan & 41 & 44,6 \\
\hline \multicolumn{3}{|l|}{ Umur } \\
\hline $50-60$ & 20 & 21,7 \\
\hline $61-70$ & 31 & 33,7 \\
\hline $71-80$ & 32 & 34,8 \\
\hline $81-90$ & 9 & 9,8 \\
\hline \multicolumn{3}{|l|}{ Pendidikan } \\
\hline Kurang & 11 & 36,7 \\
\hline Baik & 19 & 63,3 \\
\hline \multicolumn{3}{|l|}{ Sikap } \\
\hline SD & 9 & 9,8 \\
\hline SMP & 39 & 42,4 \\
\hline SMA & 29 & 31,5 \\
\hline Sarjana & 15 & 16,3 \\
\hline \multicolumn{3}{|l|}{ Pekerjaan } \\
\hline Tidak bekerja & 35 & 38,0 \\
\hline PNS & 20 & 21,7 \\
\hline Pedagang/Wiraswasta & 16 & 17,4 \\
\hline Pensiunan & 21 & 22,8 \\
\hline \multicolumn{3}{|l|}{ Pengetahuan } \\
\hline Baik & 37 & 40,2 \\
\hline Tidak baik & 55 & 59,8 \\
\hline \multicolumn{3}{|l|}{ Peran Petugas } \\
\hline Baik & 33 & 35,9 \\
\hline Tidak baik & 59 & 64,1 \\
\hline \multicolumn{3}{|l|}{ Dukungan Keluarga } \\
\hline Baik & 42 & 45,7 \\
\hline Tidak baik & 50 & 54,3 \\
\hline \multicolumn{3}{|l|}{ Kebutuhan Akan Pelayanan } \\
\hline Baik & 43 & 46,7 \\
\hline Tidak baik & 49 & 53,3 \\
\hline \multicolumn{3}{|l|}{ Pemanfaatan Prolanis } \\
\hline Memanfaatkan Prolanis & 40 & 43,5 \\
\hline Tidak Memanfaatkan Prolanis & 52 & 56,5 \\
\hline Total & 92 & 100,0 \\
\hline
\end{tabular}

Dari 37 responden yang pengetahuannya baik, responden yang memanfaatkan program Prolanis sebanyak 23 orang (62,2\%) dan responden yang tidak memanfaatkan program Prolanis sebanyak 14 orang $(37,8 \%)$ (lihat Tabel 2). Sedangkan dari 55 responden yang pengetahuannya tidak baik, responden yang tidak memanfaatkan Prolanis sebanyak 38 orang $(69,1 \%)$ dan yang memanfaatkan Prolanis sebanyak 17 orang (30,9\%). Hasil uji Chi-Square diperoleh nilai $p$ value $0,003(p<0,05)$, artinya ada pengaruh yang signifikan antara pengetahuan dengan pemanfaatan Prolanis.

Dari 33 responden yang menyatakan petugas berperan baik, responden yang me- manfaatkan Prolanis sebanyak 20 orang $(60,6 \%)$ dan yang tidak memanfaatkan Prolanis sebanyak 13 orang $(39,4 \%)$. Dari 59 responden yang menyatakan petugas berperan tidak baik, responden yang tidak memanfaatkan Prolanis sebanyak 39 orang $(66,1 \%)$ dan yang memanfaatkan Prolanis sebanyak 20 orang $(33,9 \%)$. Dengan nilai $p 0,013(p>0,05)$ artinya tidak ada pengaruh yang signifikan antara peran petugas dengan pemanfaatan Prolanis.

Selanjutnya dari 42 responden yang mendapat dukungan keluarga, mayoritas responden yang memanfaatkan Prolanis sebanyak 26 orang $(61,9 \%)$ dan responden yang tidak memanfaatkan Prolanis sebanyak 16 
orang $(38,1 \%)$. Dari 50 responden yang tidak mendapat dukungan keluarga, responden yang tidak memanfaatkan Prolanis sebanyak 36 orang $(72,0 \%)$ dan yang memanfaatkan Prolanis sebanyak 14 orang $(28,0 \%)$. Hasil uji
Chi-Square diperoleh $p$ value 0,001 maka dapat diartikan ada pengaruh yang signifikan antara dukungan keluarga dengan pemanfaatan Prolanis.

Tabel 2. Hasil uji Chi-Square

\begin{tabular}{|c|c|c|c|c|c|c|c|}
\hline \multirow{3}{*}{ Variabel } & \multicolumn{4}{|c|}{ Pemanfaatan Prolanis } & \multirow{2}{*}{\multicolumn{2}{|c|}{ Total }} & \multirow{3}{*}{ p value } \\
\hline & \multicolumn{2}{|c|}{ Memanfaatkan } & \multicolumn{2}{|c|}{ Tidak Memanfaatkan } & & & \\
\hline & $\mathbf{N}$ & $\%$ & $\mathbf{N}$ & $\%$ & $\mathbf{N}$ & $\%$ & \\
\hline \multicolumn{8}{|l|}{ Pengetahuan } \\
\hline Baik & 23 & 62,2 & 14 & 37,8 & 37 & 100 & 0,003 \\
\hline Tidak Baik & 17 & 30,9 & 38 & 69,1 & 55 & 100 & \\
\hline \multicolumn{8}{|l|}{ Peran Petugas } \\
\hline Baik & 20 & 60,6 & 13 & 39,4 & 33 & 100 & 0,013 \\
\hline Tidak Baik & 20 & 33,9 & 39 & 66,1 & 59 & 100 & \\
\hline \multicolumn{8}{|l|}{ Dukungan Keluarga } \\
\hline Baik & 26 & 61,9 & 16 & 38,1 & 42 & 100 & 0,001 \\
\hline Tidak baik & 14 & 28,0 & 36 & 72,0 & 50 & 100 & \\
\hline \multicolumn{8}{|l|}{ Kebutuhan Akan Pelayanan } \\
\hline Membutuhkan & 17 & 39,5 & 26 & 60,5 & 43 & 100 & 0,475 \\
\hline Tidak Membutuhkan & 23 & 46,9 & 26 & 53,1 & 49 & 100 & \\
\hline
\end{tabular}

Dari 43 responden yang membutuhkan pelayanan kesehatan, responden yang tidak memanfaatkan Prolanis sebanyak 26 orang $(60,5 \%)$ dan responden yang memanfaatkan Prolanis sebanyak 17 orang (39,5\%). Dari 49 responden yang tidak membutuhkan pelayanan kesehatan, responden yang tidak memanfaatkan Prolanis sebanyak 26 orang $(53,1 \%)$ dan responden yang memanfaatkan Prolanis sebanyak 23 orang (46,9\%). Denga nilai $p$ sebesar 0,475 ( $p$ value $>0,05$ ), artinya tidak ada pengaruh yang signifikan antara kebutuhan akan pelayanan dengan pemanfaatan Prolanis.

\section{Pembahasan}

Hasil analisis pada hubungan pengetahuan dengan pemanfaatan diperoleh kesimpulan ada pengaruh yang signifikan antara pengetahuan dengan pemanfaatan Prolanis di Puskesmas Darussalam Medan Petisah. Penelitian yang dilakukan oleh Viona (2018) menunjukkan pengaruh yang signifikan antara pengetahuan peserta terhadap pemanfaatan Program Pengelolaan Penyakit Kronis. ${ }^{12}$ Notoatmodjo (2012) menyatakan bahwa pengetahuan adalah hasil tahu yang sesuai setelah seseorang melakukan penca inderanya. Semakin banyak yang dilihat dan didengar seseorang maka semakin tinggi pengetahuannya. Pengetahuan atau ranah kognitif merupakan domain yang sangat penting dalam membentuk tindakan seseorang (overt behavior). Tingkat pengetahuan seseorang terhadap suatu objek memiliki intensitas yang berbeda beda. ${ }^{13}$

Berdasarkan hasil penelitian bahwa masih banyak responden yang pengetahuannya kurang baik mengenai program Prolanis di Puskesmas Darussalam hal ini dikarenakan mereka kurang mendapat informasi tentang program tersebut, sehingga mereka pun kurang memanfaatkan program Prolanis. Tingkat pengetahuan seseorang tidak hanya ditentukan berdasarkan pendidikan tingkat formal saja namun juga berdasarkan informasi yang diperoleh, pengalaman, dan sosial ekonomi.Pengetahuan dan informasi yang telah didapat diharapakan dapat memberikan motivasi dan kesadaran untuk mau memanfaakan pelayanan program pengelolaan penyakit kronis di puskesmas.

Hasil analisis bivariat menunjukkan tidak ada pengaruh yang signifikan antara peran petugas dengan pemanfaatan program Prolanis di Puskesmas Darussalam Medan Petisah. Berdasarkan hasil penelitian, petugas kesehatan juga mengaku tidak melakukan kegiatan khusus untuk mensosialisasikan program ini. Petugas menyatakan bahwa mereka baru akan memberikan informasi kegiatan jikalau pen- 
derita telah melakukan pengobatan yang berulang-ulang. Dukungan dan arahan petugas kesehatan merupakan kunci keberhasilan sistem pelayanan di puskesmas. Jika dukungan dan arahan yang diberikan petugas kesehatan kurang aktif, maka program yang dijalankan tidak akan mendapat respon positif dari penderita hipertensi dan DM untuk mau mengikuti kegiatan prolanis.

Studi yang dilakukan oleh Auliya (2018) tentang Pengaruh Informasi Pelayanan Prolanis dan Kesesuaian Waktu Terhadap Pemanfaatan Prolanis di Pusat Layanan Kesehatan UNAIR menunjukkan hasil uji regresi logistik variabel petugas kesehatan didapatkan $p$-value sebesar $1,000(p>\alpha)$, artinya tidak berpengaruh signifikan terhadap pemanfaatan Prolanis. ${ }^{14}$

Undang-Undang Republik Indonesia Nomor 36 Tahun 2014 Tentang Tenaga Kesehatan menyatakan setiap orang yang mengabdikan diri dalam bidang kesehatan serta memiliki pengetahuan dan/atau keterampilan melalui pendidikan di bidang kesehatan yang untuk jenis tertentu memerlukan kewenangan untuk melakukan upaya kesehatan. ${ }^{15}$ Petugas kesehatan sebaiknya memberikan motivasi berupa pemberian informasi penting terkait penyakit kronis begitu juga bagaimana komplikasi yang akan terjadi jika tidak dilakukan pencegahan, agar penyandang penyakit kronis khususnya penyakit Diabetes Mellitus Tipe 2 dan penyakit Hipertensi mau mengikuti kegiatan program pengelolaan penyakit kronis.

Hasil uji Chi-Square menunjukkan ada hubungan yang signifikan antara dukungan keluarga dengan pemanfaatan program prolanis di Puskesmas Darussalam Medan Petisah. Keluarga merupakan kelompok yang mempunyai peranan yang amat penting dalam mengembangkan, mencegah, mengadaptasi dan atau memperbaiki masalah kesehatan yang ditemukan dalam keluarga. Untuk mencapai perilaku sehat masyarakat, maka harus dimulai pada masing-masing tatanan keluarga. Keluarga merupakan tempat yang kondusif untuk tempat tumbuhnya perilaku sehat bagi anak-anak sebagai calon anggota masyarakat, maka promosi sangat berperan. ${ }^{16}$

Dukungan dari keluarga sangat berpengaruh dengan terlaksananya Prolanis, kenyataan yang terjadi di Puskesmas Darussalam masih banyak responden yang tidak mendapat dukungan dari keluarganya sehingga responden pun banyak yang tidak memanfaatkan Prolanis. Dukungan dari keluarga dalam hal ini bisa berupa saran untuk memanfaatkan prolanis. Kesediaan anggota keluarga untuk menemani dan mengantar responden juga merupakan salah satu bukti dukungan dari keluarga tetapi nyatanya masih banyak responden terutama pada lansia mereka datang dengan sendirinya tanpa ada yang ditemani oleh anggota keluarganya. Semakin banyak dukungan keluarga yang diberikan maka akan semakin besar peluang dan keinginan seseorang untuk sehat. Namun hasil penelitian Auliya (2018) menunjukkan hubungan sosial atau dukungan keluarga tidak berpengaruh signifikan terhadap pemanfaatan Prolanis.

Pada hasil analisis hubungan kebutuhan akan pelayanan ternyata tidak ada pengaruh yang signifikan dengan pemanfaatan Prolanis di Puskesmas Darussalam Medan Petisah. Hal ini terbukti pada saat terjun langsung ke lapangan responden yang mengikuti kegiatan senam kesehatan, edukasi kesehatan, dan pemeriksaan kesehatan hanya sedikit yang menghadiri kegiatan prolanis tersebut.

Notoadmodjo (2012) menyatakan bahwa jumlah penggunaan pelayanan kesehatan oleh suatu keluarga merupakan karakteristik disposisi, kemampuan serta kebutuhan keluarga itu atas pelayanan medis, semua komponen tersebut dianggap mempunyai peranan tersendiri dalam memahami perbedaan pemanfaatan pelayanan kesehatan, sedangkan kebutuhan merupakan faktor yang lebih penting dibandingkan faktor predisposisi dan kemampuan. ${ }^{17}$

Penelitian Auliya (2018) menunjukkan variabel kebutuhan tidak berpengaruh signifikan terhadap pemanfaatan Prolanis di PLK Unair. Besarnya kebutuhan peserta terhadap kegiatan Prolanis bukan menjadi faktor utama yang memberikan pengaruh signifikan terhadap pemanfaatan kegiatankegiatan Prolanis di PLK Unair. ${ }^{14}$

\section{Kesimpulan}

Penelitian ini menyimpulkan adanya pengaruh pengetahuan dan dukungan keluarga terhadap pemanfaatan Program Pengelolaan Penyakit Kronis (Prolanis) pada lansia di Puskesmas Darussalam. Sedangkan peran petugas dan kebutuhan akan pelayanan tidak 
berpengaruh signifikan terhadap pemanfaatan Program Pengelolaan Penyakit Kronis (Prolanis) pada lansia di Puskesmas Darussalam. Dari hal tersebut maka pengetahuan responden perlu ditingkatkan dengan cara melakukan sosialisasi tentang program tersebut serta selalu diberikan motivasi dan informasi, dukungan keluarga juga perlu diberikan secara terus menerus kepada responden agar program Prolanis di Puskesmas Darussalam lebih dimanfaatkan terutama pada lansia yang menderita penyakit Hipertensi dan Diabetes Mellitus.

\section{Referensi}

1. BPJS Kesehatan. Panduan Praktis Prolanis (Program Pengelolaan Penyakit Kronis). BPJS Kesehatan. Jakarta: 2014.

2. Larsen PD, Lubkin IM. Lubkin's Chronic Illness: Impact and Intervention. Edisi ke10. Jones and Bartlett. Massachusetts: 2009.

3. World Health Organization. Global Report On Diabetes. France: 2017.

4. Kemenkes RI. Profil Kesehatan Indonesia 2016. Pusat Data dan Informasi Kesehatan Republik Indonesia. Jakarta: 2017.

5. World Health Organization. 2014. Noncommunicable diseases. Diperoleh dari http://www.who.int/mediacentre/factshe ets/fs355/en/.

6. Badan Pusat Statistik. Statistik Penduduk Lanjut Usia Indonesia 2011. Badan Pusat Statistik. Jakarta: 2011.

7. Kemenkes RI. Profil Kesehatan Indonesia 2009. Pusat Data dan Informasi Kesehatan Republik Indonesia. Jakarta: 2010.

8. Dinas Kesehatan Kota Medan. Profil Kesehatan Kota Medan Tahun 2016. Medan. 2017.

9. Puskesmas Darussalam. Profil Kesehatan Puskesmas Mandala Tahun 2017. Medan. 2018.

10. Abdullah, Sjattar EL, Kadir AR. Faktor Penyebab Terjadinya Penurunan Jumlah Kunjungan Peserta Program Pengelolaan Penyakit Kronis (Prolanis) di Puskesmas Minasa Upa Kota Makassar. Jurnal IImiah Kesehatan Diagnosis, Vol.11 No. 04, p. 382-387: 2017.

11. Rahmi A. Faktor-Faktor Yang Berhubungan Dengan Pemanfaatan Program Pengelo- laan Penyakit Kronis (Prolanis) di BPJS Kesehatan Kantor Cabang Jakarta Timur Tahun 2015. Fakutas Kesehatan Masyarakat Universitas Indonesia. 2015.

12. Viona Y. Faktor-Faktor yang Mempengaruhi Pemanfaatan Prolanis di Wilayah Kerja Puskesmas Mandala Kecamatan Medan Tembung Tahun 2018. Fakutas Kesehatan Masyarakat Universitas Sumatera Utara. 2018.

13. Notoatmodjo S. Metodologi Penelitian Kesehatan. Rineka Cipta. Jakarta: 2010.

14. Arifa AFC. Pengaruh Informasi Pelayanan Prolanis dan Kesesuaian Waktu Terhadap Pemanfaatan Prolanis di Pusat Layanan Kesehatan UNAIR. Jurnal Administrasi Kesehatan Indonesia Vol.6 No.2: 2018.

15. Pemerintah Republik Indonesia. UndangUndang Republik Indonesia Nomor 36 Tahun 2014 Tentang Tenaga Kesehatan.

16. Notoatmodjo S. Ilmu Perilaku Kesehatan. Rineka Cipta. Jakarta: 2010. 